\title{
Thermal stability of anthocyanin in mixed raspberry-pomegranate- banana nectar in the presence of ascorbic acid and citric acid
}

\author{
Nguyen Minh Thuy* (D), Lu Ngoc Han, Ngo Van Tai (it) \\ Department of Food Technology, College of Agriculture, Can Tho University, Can Tho, Vietnam.
}

\section{ARTICLE INFO \\ Article history: \\ Received on: July 06, 2021 \\ Accepted on: September 05, 2021 \\ Available online: January 07, 2022}

\section{Key words:}

Anthocyanin, degradation kinetic, raspberry-pomegranate-banana nectar, storage, thermal processing

\begin{abstract}
Thermal food processing, which causes the alteration and decomposition of natural pigments, especially anthocyanins, often leads to its lower stability. This study aimed to determine the effect of ascorbic acid and citric acid and the combination of these two chemicals on the thermal stability of the anthocyanin in the raspberry-pomegranate-banana nectar during heating at different temperatures $\left(85^{\circ} \mathrm{C}, 90^{\circ} \mathrm{C}\right.$, and $\left.95^{\circ} \mathrm{C}\right)$ and also investigated the influence of storage conditions $\left(8^{\circ} \mathrm{C} \pm 2^{\circ} \mathrm{C}\right.$ and $\left.28^{\circ} \mathrm{C} \pm 2^{\circ} \mathrm{C}\right)$ on the stability of anthocyanin in the product. Anthocyanin degradation during heating as well as storage was followed by a first-order kinetic model with a high coefficient of determination $\left(R^{2}>0.94\right)$ and low root-mean-square error (RMSE $\left.<0.015\right)$. By combining ascorbic acid and citric acid used in the nectar, anthocyanin showed more stability during pasteurization. It was found that the highest anthocyanin stability during storage was obtained at $8^{\circ} \mathrm{C} \pm 2^{\circ} \mathrm{C}$ and the half-life was 11.76 weeks.
\end{abstract}

\section{INTRODUCTION}

Raspberry and its products are of interest because of their phenolic components, especially quercetin and ellagic acid. Currently, there is increasing interest in raspberries as a source of antioxidants, such as anthocyanins, catechins, flavonols, flavones, and ascorbic acid, as they may protect against a variety of diseases [1]. Moderate consumption of raspberry juice may help prevent the development of early atherosclerosis, with underlying mechanisms involved in improving antioxidant status [2]. Pomegranate may help prevent or treat various disease risk factors including high blood pressure, high cholesterol, oxidative stress, hyperglycemia, and inflammatory activities. The antioxidant potential of pomegranate juice is greater than that of red wine and green tea [3]. Pomegranate juice can reduce macrophage oxidative stress, free radicals, and lipid peroxidation. Furthermore, pomegranate extract suppresses cell growth and induces apoptosis (the process of cell death of multicellular organisms), which may lead to its anticancer effects. In addition, pomegranate extract inhibits several

\footnotetext{
*Corresponding Author

Nguyen Minh Thuy, Department of Food Technology, College of Agriculture, Can Tho University, Can Tho, Vietnam.

E-mail:nmthuy@ctu.edu.vn
}

inflammatory markers and suppresses the inflammatory process through ellagitannin [4]. Bananas are common for their aroma and taste, being consumed mainly as fresh fruit. Bananas are very susceptible to spoilage due to rapid decomposition when ripe and inadequate cold storage techniques. A considerable amount of this fruit is wasted due to improper processing and storage techniques [5]. Most bananas are generally not suitable for the fresh market because they are too ripe to be shipped. The banana fruit can compete in the market as a banana juice or a blend with other juices because it is prized for its taste and nutritional value [6].

Nectar is a beverage prepared from the juice or pulp of one or more fruits, plus water and sugar in concentration, resulting in an "instant drink" product. Recently, the market for such products has expanded dramatically. Juice blends have a wide range of advantages, such as the combination of different odors and flavors and their nutritional components [7]. Current research suggests that a diet rich in bioactive compounds which are provided in fruits and vegetables may play an important role in protecting the body from degenerative diseases $[8,9]$. By combining fruit juices including raspberry, pomegranate, and banana, a new product has been created with high nutritional and sensory properties, especially the natural sugar source from bananas and anthocyanins from red raspberries and pomegranates. 
Anthocyanins are a group of naturally occurring phenolic compounds, which are responsible for the attractive colors of many flowers, fruits (particularly in berries), and vegetables and related products derived from them. Heat treatment is one of the most widely used methods of preserving and extending the useful shelf life of foods. It is also one of the most important factors that affect the stability of anthocyanins. There are many influencing factors on anthocyanin stability such as temperature, $\mathrm{pH}$, the chemical structure of the anthocyanin compound, UV light, oxygen, oxidative and hydrolytic enzymes, and proteins [10]. The thermal stability of anthocyanins could be improved by increasing the anthocyanin concentration or by removing oxygen or oxidizing enzymes during processing [11]. Moreover, some research studies showed that the higher stability of anthocyanin was found under acid conditions (natural presence of acid in fruit or by adding other sources) $[12,13]$. Accurate knowledge of the kinetic parameters is essential to predict the quality changes that occur during thermal processing and storage. Therefore, the main objective was the evaluation of thermal degradation of anthocyanins from nectar during heating at a temperature range between 85 and $95^{\circ} \mathrm{C}$ and storage at $8 \pm 2$ and $28 \pm 2{ }^{\circ} \mathrm{C}$ on the kinetic basis.

\section{MATERIALS AND METHODS}

\subsection{Materials}

Raspberry was supplied from Bio Fresh Limited Company, Lam Vien Square, Ward 10, Da Lat City, Lam Dong Province. Raw materials were washed and put into PA bags, stored in a freezer for further study.

Pomegranate was bought from Xuan Khanh Market, Xuan Khanh Ward, Ninh Kieu District, Can Tho City. Raw materials were peeled and put into PA bags, stored in a freezer for the research.

Bananas were purchased from the orchard in Phong Dien District, Can Tho City, Vietnam. Refined sugar (Bien Hoa Sugar Joint Stock Company) was purchased at Coopmart-Can Tho. Foodgrade citric acid and ascorbic acid were used.

\subsection{Preparation of Raspberry-Pomegranate-Banana Nectar}

The frozen raspberries were ground in water with a ratio of fruits and water of $1: 3(\mathrm{w} / \mathrm{v})$.

The peeled bananas were washed with tap water, hydrolyzed with pectinase at a concentration of $0.05 \%$ for 120 minutes, and supplemented with ascorbic acid at a concentration of $1,000 \mathrm{ppm}$ at ambient temperature [14].

The pomegranate seeds were hydrolyzed by pectinase at a concentration of $0.2 \%$ for 60 minutes at ambient temperature [15]. The juice was obtained from the filtration process.

All the extracts were combined in nectar processing (mixed nectar) with a ratio of raspberry, pomegranate, and banana of 45:28:27 (\%), respectively. The total soluble solid content of the mixed nectar was $12^{\circ}$ Brix.

The experiment was designed with $\mathrm{A}_{1}$ : mixed nectar (control sample), $\mathrm{A}_{2}$ : mixed nectar with $200 \mathrm{ppm}(\mathrm{w} / \mathrm{v})$ ascorbic acid, $\mathrm{A}_{3}$ : mixed nectar with $200 \mathrm{ppm}(\mathrm{w} / \mathrm{v})$ citric acid, and $\mathrm{A}_{4}$ : mixed nectar with $100 \mathrm{ppm}(\mathrm{w} / \mathrm{v})$ ascorbic acid and $100 \mathrm{ppm}(\mathrm{w} / \mathrm{v})$ citric acid.

\subsection{Degradation Kinetic Studies}

Kinetic degradation of anthocyanin was determined at different temperatures $\left(85^{\circ} \mathrm{C}, 90^{\circ} \mathrm{C}\right.$, and $\left.95^{\circ} \mathrm{C}\right)$ for 11 minutes. A glass tube filled with $15 \mathrm{ml}$ combined nectar was capped and covered with aluminum foil before being placed in a water bath (Memmert, Germany) at the desired temperature. After heating for 0 (control), 3, 5, 7, 9, and 11 minutes, the sample was rapidly cooled in iced water $\left(0^{\circ} \mathrm{C}\right)$ for 5 minutes to stop the reaction. Total anthocyanin content was determined by the $\mathrm{pH}$ differential method [10]. Briefly, $1 \mathrm{ml}$ of the extract was reacted with potassium chloride buffer $(0.0025 \mathrm{M}, \mathrm{pH} 1.0)$ and sodium acetate buffer $(0.4 \mathrm{M}, \mathrm{pH} 4.5)$. The mixture was incubated for 15 minutes at ambient temperature. The absorbance of each dilution was measured at 510 and $700 \mathrm{~nm}$ on a blank cuvette filled with distilled water. The calculation of total anthocyanin is based on the equation described by Giusti and Wrolstad [10].

The stability of anthocyanins was reported in terms of degradation rate constant and half-life. Zero-order and firstorder kinetic models were explored and the model that best fit the results was selected based on the highest $\mathrm{R}^{2}$ and the lowest root-mean-square error (RMSE) values [16]. These statistical values can be calculated as in the following equation 1 and 2 , respectively:

$R^{2}=\frac{N \sum_{i=1}^{N} M_{a, i} M_{\mathrm{exp}, i}-\sum_{i=1}^{N} M_{\mathrm{pre}, i} \sum_{i=1}^{N} M_{\mathrm{exp}, i}}{\sqrt{\left(N \sum_{i=1}^{N} M_{\mathrm{pre}, i}^{2}-\left(\sum_{i=1}^{N} M_{\mathrm{pre}, i}\right)^{2}\right)\left(\sum_{i=1}^{N} M_{\mathrm{exp}, i}^{2}-\left(\sum_{i=1}^{N} M_{\mathrm{exp}, i}\right)^{2}\right)}}$

$\operatorname{RMSE}=\left[\frac{1}{N} \sum_{i=1}^{N}\left(M_{\mathrm{pre}, i}-M_{\mathrm{exp}, i}\right)^{2}\right]^{1 / 2}$

where $M_{\exp , i}$ and $M_{\mathrm{pre}, i}$ are the experimental and predicted data at observation $i$ and $N$ is the number of the experimental data points.

The degradation rate of anthocyanin during thermal processing and storage could be described by zero-order and first-order models (Equation $3 \& 4$ ) under constant temperature condition:

$$
\begin{aligned}
& C=-k t+C_{o}, \\
& \ln \left(C / C_{o}\right)=-k t,
\end{aligned}
$$

where $C_{o}$ is the initial concentration of anthocyanin $(\mathrm{mg} / \mathrm{l}), C$ is anthocyanin content at the treatment time $(\mathrm{mg} / \mathrm{l}), k$ is the degradation rate constant (minute ${ }^{-1} / \mathrm{week}^{-1}$ ), and $t$ is the treatment time (minute/week).

The half-life $\left(t_{1 / 2}\right)$ of the reaction (minute/week) was calculated assuming the first-order kinetics according to equation 5 and 6 .

for zero-order kinetic: $\quad t_{1 / 2}=C_{o} / 2 k$,

for first-order kinetic: $\quad t_{1 / 2}=\ln (2) / k$.

The Arrhenius model (Equation 7) was used to describe the temperature dependence of degradation rate constants and the activation energy $\left(E_{a}, \mathrm{~kJ} / \mathrm{mol}\right)[16]$ : 


$$
k=k_{o} \operatorname{expu}\left(\frac{-E_{a}}{R T}\right)
$$

where $k_{o}$ is the frequency factor (per minute), $E_{a}$ is the activation energy $\left(\mathrm{J} \cdot \mathrm{mol}^{-1}\right), R$ is the universal gas constant $\left(8.314 \mathrm{~J} \cdot \mathrm{mol}^{-1}\right.$. $\left.\mathrm{K}^{-1}\right)$, and $T$ is the absolute temperature $(\mathrm{K})$.

After selecting the heating temperature and the sensory test, the selected sample was chosen for storage at $8^{\circ} \mathrm{C} \pm 2{ }^{\circ} \mathrm{C}$ and $28^{\circ} \mathrm{C} \pm$ $2^{\circ} \mathrm{C}$. The change of anthocyanin was also tested during an 8 -week storage period.

\subsection{Statistical Analysis of Data}

All experiments were performed in triplicate and the results were expressed in terms of average values. Statistical analysis of the data was performed using the data analysis tool pack of the Microsoft Excel software and STATGRAPHICS Centurion XV.I (USA). The coefficient of determination and RMSE were used as criteria for adequacy of fit.

\section{RESULTS AND DISCUSSION}

\subsection{Model Fitting}

The degradation of total anthocyanin of the mixed nectar was studied and fitted with two common empirical models. Kinetic models are often used as a fast and economic assessment of food safety. The influence of processing on critical quality parameters may also be employed by kinetic modeling. Knowledge of degradation kinetics, including reaction order, rate constant, and activation energy, is of great importance to predict food quality loss during thermal process treatment $[10,11,16]$. It was observed that the initial anthocyanin content of samples was $30.615 \pm 0.192 \mathrm{mg} / \mathrm{l}$. A general decline trend was obtained in the anthocyanin retention of the mixed nectar after thermal processing. Heating caused the loss of anthocyanin in the product, ranging from $43.34 \%$ to $52.42 \%$, from $25.45 \%$ to $36.38 \%$, from $35.54 \%$ to $39.72 \%$, and from $22.19 \%$ to $33.11 \%$ corresponding to samples $\mathrm{A}_{1}, \mathrm{~A}_{2}, \mathrm{~A}_{3}$, and $\mathrm{A}_{4}$ after the temperature increased from $85^{\circ} \mathrm{C}$ to $95^{\circ} \mathrm{C}$. The heat processing of the product should be controlled to maintain more bioactive compounds in the product [16]. The kinetics of anthocyanin composition change in four samples was fitted by zero-order and first-order models, which are shown in Table 1.

All models presented determination coefficient values $\left(R^{2}\right)$ close to 1 , which showed a good fit between the predicted and observed data. The goodness of fit of the model was qualified by the coefficient of determination and RMSE. It could be seen that the first-order model showed higher $R^{2}$ and lower RMSE. The first-order model has been commonly used to describe nutrient degradation such as anthocyanins which have been applied in different products [17-19]. Therefore, the first-order model could describe the effect of thermal processing on anthocyanin content in the mixed nectar.

The degradation rate $(k)$ increases as the temperature increases, demonstrating that the greater the temperature, the greater the anthocyanin degradation (Fig. 1).

The $k$ values $\left(10^{-2}\right)$ varied from 5.67 to 7.56 , from 2.58 to 4.67 , from 3.82 to 5.48 , and from 2.18 to 4.06 minute $^{-1}$ for samples $\mathrm{A}_{1}, \mathrm{~A}_{2}, \mathrm{~A}_{3}$, and $\mathrm{A}_{4}$, respectively, at $85^{\circ} \mathrm{C}-95^{\circ} \mathrm{C}$. A significant increase in the rate of degradation was observed with increasing time; it was similar to the study of Charurungsipong et al. [16]. The rate of anthocyanin degradation upon heating increased because the reacting molecules were closer together [20]. Given the values of the degradation rate constants, it can be stated that monomeric anthocyanins degrade with the highest rate, due to oxidation, cleavage of covalent bonds, or enhanced oxidation reactions due to thermal processing [21]. Probably during heat treatment, anthocyanins or their conjugated sugars are broken down into small molecules such as aldehydes and benzoic acid derivatives or their corresponding anthocyanidins. In addition, the lowest and highest rates of degradation were observed in sample $\mathrm{A}_{4}$ (100 ppm ascorbic acid and $100 \mathrm{ppm}$ citric acid added) and sample $A_{1}$ (without the addition of ascorbic acid and citric acid), respectively. In addition, the lower $k$ value was achieved in sample $A_{2}$ in the comparison between samples $A_{2}$ and $A_{3}$. It could be concluded that a protective effect of the mixed nectar was observed

Table 1: Parameters used to evaluate the performance of selected models to describe anthocyanin degradation in the mixed nectar at different temperatures.

\begin{tabular}{|c|c|c|c|c|c|c|c|}
\hline \multirow{2}{*}{ Sample } & \multirow{2}{*}{$\begin{array}{c}\text { Temperature } \\
\left({ }^{\circ} \mathrm{C}\right)\end{array}$} & \multicolumn{3}{|c|}{ Zero-order model } & \multicolumn{3}{|c|}{ First-order model } \\
\hline & & $k$ (minute $\left.{ }^{-1}\right)$ & $R^{2}$ & RMSE & $k\left(\right.$ minute $\left.^{-1}\right)$ & $R^{2}$ & RMSE \\
\hline \multirow[t]{3}{*}{$\mathrm{A}_{1}:$ mixed nectar } & 85 & 1.373 & 0.934 & 2.893 & 0.0567 & 0.969 & 0.085 \\
\hline & 90 & 1.555 & 0.951 & 2.829 & 0.0671 & 0.988 & 0.063 \\
\hline & 95 & 1.703 & 0.892 & 4.474 & 0.0756 & 0.951 & 0.140 \\
\hline \multirow{3}{*}{$\begin{array}{l}\mathrm{A}_{2}: \text { mixed nectar with } 200 \\
\text { ppm ascorbic acid }\end{array}$} & 85 & 0.701 & 0.988 & 0.705 & 0.0258 & 0.981 & 0.034 \\
\hline & 90 & 1.015 & 0.992 & 0.787 & 0.0396 & 0.989 & 0.038 \\
\hline & 95 & 1.178 & 0.916 & 2.763 & 0.0467 & 0.951 & 0.086 \\
\hline \multirow{3}{*}{$\begin{array}{l}A_{3}: \text { mixed nectar with } 200 \\
\text { ppm citric acid }\end{array}$} & 85 & 0.991 & 0.989 & 0.877 & 0.0382 & 0.996 & 0.021 \\
\hline & 90 & 1.148 & 0.900 & 3.025 & 0.0453 & 0.921 & 0.110 \\
\hline & 95 & 1.346 & 0.815 & 4.504 & 0.0548 & 0.876 & 0.154 \\
\hline \multirow{3}{*}{$\begin{array}{l}\mathrm{A}_{4} \text { : mixed nectar with } 100 \\
\text { ppm ascorbic acid and } 100 \\
\text { ppm citric acid }\end{array}$} & 85 & 0.602 & 0.956 & 1.285 & 0.0218 & 0.944 & 0.053 \\
\hline & 90 & 0.804 & 0.974 & 1.246 & 0.0302 & 0.951 & 0.067 \\
\hline & 95 & 1.045 & 0.957 & 1.872 & 0.0406 & 0.961 & 0.065 \\
\hline
\end{tabular}




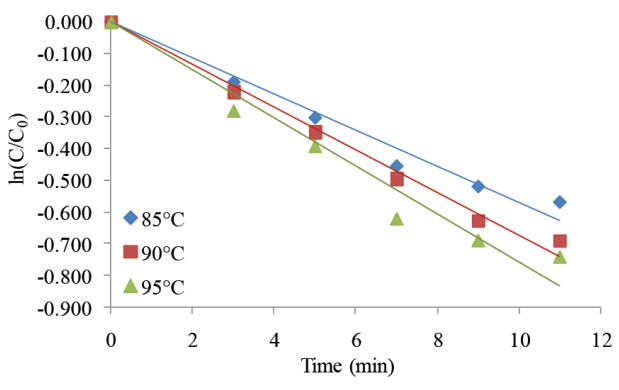

A1

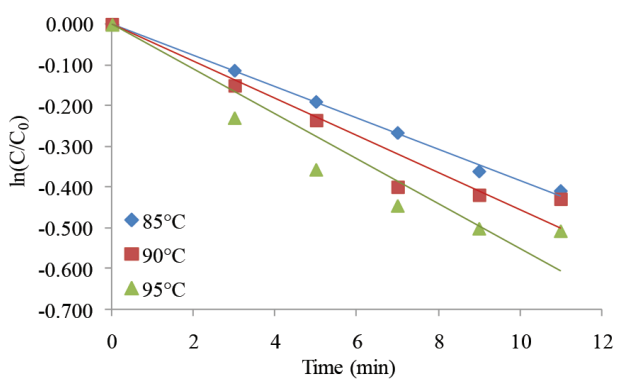

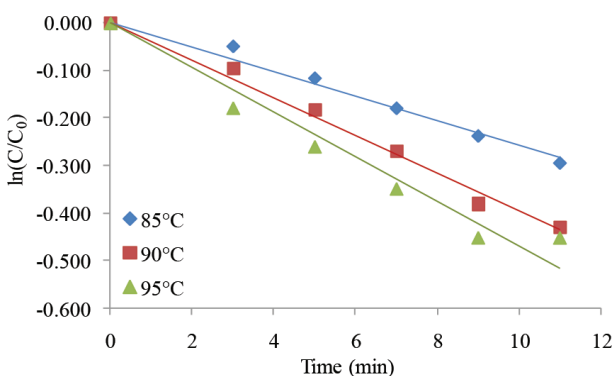

$\mathbf{A}_{2}$

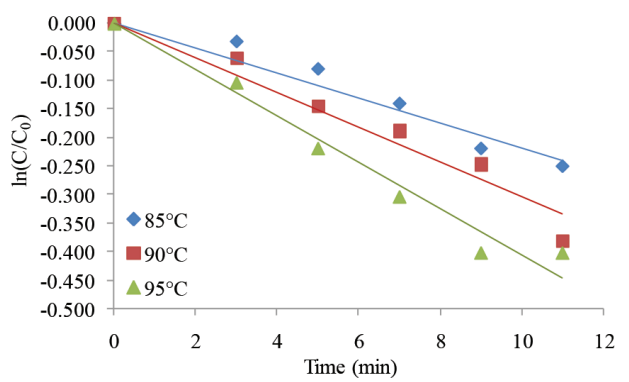

Figure 1: Degradation of anthocyanin of the mixed nectar during thermal processing as described by the first-order kinetic model. $A_{1}$ : mixed nectar (control sample), $A_{2}$ : mixed nectar with $200 \mathrm{ppm}$ ascorbic acid, $\mathrm{A}_{3}$ : mixed nectar with $200 \mathrm{ppm}$ citric acid, and $\mathrm{A}_{4}$ : mixed nectar with $100 \mathrm{ppm}$ ascorbic acid and $100 \mathrm{ppm}$ citric acid.

in the samples with the combination of ascorbic acid and citric acid. The previous studies reported that the higher stability of anthocyanin was found under acidic conditions. It can be noticed that the presence of acid and sugar and their combination had a positive influence on the stability of anthocyanins' thermal degradation [12,13]. In food processing, ascorbic acid and citric acid have been used as an acidifier and antioxidant compound which can help to not only balance taste between sweet and sour in the product but also protect the color or control the browning and degradation process during thermal processing [22,23]. Shaheer et al. [24] reported that the presence of an acidifier such as citric acid and ascorbic acid created the higher anthocyanin thermostability due to the diacylation of structure. In addition, the acylation sites as well as the types and numbers of acyl groups influence the stability of acylated anthocyanins to different degrees. The higher stability of nectar anthocyanins in sample $\mathrm{A}_{4}$ than others could be attributed to the presence of much higher amounts of acylated anthocyanins due to the combination of two kinds of acidifiers. Moreover, some previous studies also supported that the presence of inter- and intramolecular copigmentation with other moieties and polyglycosylated and polyacylated anthocyanins provides greater stability to the change of temperature, $\mathrm{pH}$, and light [24]. Therefore, it seems that the different susceptibilities of fruit nectar anthocyanins to heat treatment might be caused by both the different anthocyanin forms and the interactions of the constituents of the fruits. Anthocyanin stability is also related to the water activity of the product; anthocyanin stability is higher when sugar is added due to the reduction of water activity [25].

The half-life and activation energy following the first-order model were calculated and are shown in Table 2 . The half-lives of the four mixed nectars were in the ranges 9.169-12.225, 14.483-26.866, 12.649-18.145, and 17.073-31.796 minutes in samples $A_{1}, A_{2}, A_{3}$, and $\mathrm{A}_{4}$, respectively. The $t_{1 / 2}$ (half-life) of anthocyanin in the mixed nectar increased with increasing treatment temperature. Anthocyanins are a natural colorant and thus they are easily degraded during heating. Nielsen et al. [26] suggested that anthocyanin pigment was changed to brown color when the product was heated at a high temperature. Many studies reported similar results where the rate of degradation increased during thermal processing due to the modification and degradation of the chemical structure of anthocyanin [27,28].

The activation energy $\left(E_{\alpha}\right)$ was determined using the slope of the straight line obtained by plotting $-\ln (k)$ against $1 / T$, according to Equation (7). The activation energy $\left(E_{a}\right)$ for anthocyanin was calculated as $30.84,63.72,38.65$, and $66.64(\mathrm{~kJ} / \mathrm{mol})$, respectively, for $\mathrm{A}_{1}, \mathrm{~A}_{2}, \mathrm{~A}_{3}$, and $\mathrm{A}_{4}$. Activation energy, $E_{a}$, is the minimum energy that molecules must have in order to react to form products. The estimated $\mathrm{E}_{\mathrm{a}}$ values of the four samples were almost lower than in some previous reports. Kurca and Cemeroğlu [29] reported that the $E_{\alpha}$ values for anthocyanins' thermal degradation in blood orange juice and concentrate were ranged from 73.2 to $89.5 \mathrm{~kJ} / \mathrm{mol}$ at $70^{\circ} \mathrm{C}-90^{\circ} \mathrm{C}, E_{a}$ value of $64.89 \mathrm{~kJ} / \mathrm{mol}$ for anthocyanins' degradation at the temperature ranged from $70^{\circ} \mathrm{C}$ to $90^{\circ} \mathrm{C}$ in grape juice [30], and $E_{a}$ value of $72.74 \mathrm{~kJ} / \mathrm{mol}$ for the thermal degradation of Bordo grape anthocyanins between $70^{\circ} \mathrm{C}$ and $90^{\circ} \mathrm{C}$ [31]. Since a high activation energy value indicates a higher sensitivity of the reaction rate to temperature, the degradation of anthocyanins in the mixed nectar with the presence of a combination of citric acid and ascorbic acid seemed to be less susceptible to temperature increase in comparison with others.

\subsection{Effect of Storage Temperature on Anthocyanin Content of Product}

The pasteurization process is designed to achieve the goal of killing pathogenic and spoilage microorganisms [32]. Heat pasteurization 
Thuy et al.: Thermal stability of anthocyanin in mixed raspberry-pomegranate-banana nectar in the presence of ascorbic acid and citric acid 2022;10(01):189-195

Table 2: Kinetic parameters for thermal degradation of anthocyanin in the mixed nectar following the first-order model.

\begin{tabular}{|c|c|c|c|c|}
\hline Sample & Temperature $\left({ }^{\circ} \mathrm{C}\right)$ & $t_{1 / 2}$ (minute) & $E_{a}(\mathrm{~kJ} / \mathrm{mol})$ & $R^{2}$ \\
\hline \multirow{3}{*}{$\mathrm{A}_{1}$ : Mixed nectar } & 85 & 12.225 & \multirow{3}{*}{30.84} & \multirow{3}{*}{0.991} \\
\hline & 90 & 10.330 & & \\
\hline & 95 & 9.169 & & \\
\hline \multirow{3}{*}{$\begin{array}{l}\mathrm{A}_{2}: \text { Mixed nectar with } 200 \mathrm{ppm} \\
\text { ascorbic acid }\end{array}$} & 85 & 26.866 & \multirow{3}{*}{63.72} & \multirow{3}{*}{0.942} \\
\hline & 90 & 17.504 & & \\
\hline & 95 & 14.843 & & \\
\hline \multirow{3}{*}{$\begin{array}{l}\mathrm{A}_{3}: \text { Mixed nectar with } 200 \mathrm{ppm} \\
\text { citric acid }\end{array}$} & 85 & 18.145 & \multirow{3}{*}{38.65} & \multirow{3}{*}{0.998} \\
\hline & 90 & 15.301 & & \\
\hline & 95 & 12.649 & & \\
\hline \multirow{3}{*}{$\begin{array}{l}\mathrm{A}_{4} \text { : Mixed nectar with } 100 \mathrm{ppm} \\
\text { ascorbic acid and } 100 \mathrm{ppm} \text { citric } \\
\text { acid }\end{array}$} & 85 & 31.796 & \multirow{3}{*}{66.64} & \multirow{3}{*}{0.99} \\
\hline & 90 & 22.952 & & \\
\hline & 95 & 17.073 & & \\
\hline
\end{tabular}

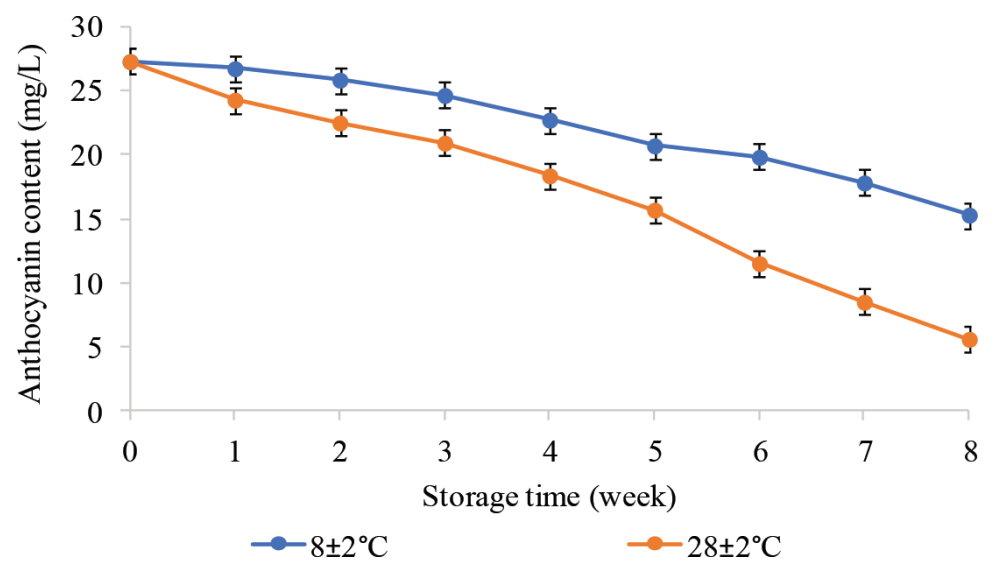

Figure 2: The change of anthocyanin in the mixed nectar during storage at different temperatures.

Table 3: The degradation rate constant $(k)$ and half-life $\left(t_{1 / 2}\right)$ of anthocyanin in the mixed nectar in storage.

\begin{tabular}{cccc} 
Temperature $\left({ }^{\circ} \mathbf{C}\right)$ & $\boldsymbol{k}\left(\right.$ week $\left.^{-1}\right)$ & $\boldsymbol{R}^{2}$ & $\boldsymbol{t}_{1 / 2}$ (week) \\
$8 \pm 2$ & $0.0591 \pm 0.004$ & 0.9637 & $11.76 \pm 0.82$ \\
$28 \pm 2$ & $0.1548 \pm 0.013$ & 0.9457 & $4.50 \pm 0.38$ \\
\hline
\end{tabular}

can cause color degradation, the appearance of strange color, odor, or taste, and loss of organoleptic value of fruit juices [33]. As per the obtained results, at $85^{\circ} \mathrm{C}$, the lowest degradation of anthocyanin in the mixed nectar was found. When the product was heated over 5 minutes, the obtained sample has the acceptable levels of microbial according to TCVN 7041:2002 standard. when the product was heated over 5 minutes. A sensory test showed that the 7 minutes pasteurized raspberry-pomegranate-banana nectar gave the best sensory value, does not produce a cooking smell when drinking, and achieves high homogeneity. For the raspberry-pomegranatebanana nectar, the product was tested for storage time at different temperatures $\left(8^{\circ} \mathrm{C} \pm 2{ }^{\circ} \mathrm{C}\right.$ and $28^{\circ} \mathrm{C} \pm 2^{\circ} \mathrm{C}$ ) for 8 weeks (Fig. 2). Anthocyanin content tended to decrease during storage, and the samples stored at cool temperature $\left(8^{\circ} \mathrm{C} \pm 2^{\circ} \mathrm{C}\right)$ maintained higher anthocyanin content than that of the samples stored at ambient temperature $\left(28^{\circ} \mathrm{C} \pm 2^{\circ} \mathrm{C}\right)$. By fitting with the first-order kinetic model, the obtained degradation rate constants were 0.0591 and $0.1548\left(\right.$ week $\left.^{-1}\right)$ for the sample storage at $8^{\circ} \mathrm{C} \pm 2^{\circ} \mathrm{C}$ and $28^{\circ} \mathrm{C} \pm$ $2^{\circ} \mathrm{C}$, respectively (Table 3 ). As the storage temperature increases, the corresponding $k$ value also increases. The obtained results are in agreement with those from the previous studies which showed that storage degradation of anthocyanins from various products is described by first-order reaction kinetics [18,20,29].

Specifically, the initial anthocyanin in the nectar was $27.27 \mathrm{mg} / \mathrm{l}$. In the first week of storage, anthocyanin content in products stored at cool and room temperatures was 26.72 and $24.27 \mathrm{mg} / \mathrm{l}$, respectively. By the fourth week, a general rapid decrease trend in anthocyanin was observed; this content of the product at room temperature was only $18.37 \mathrm{mg} / \mathrm{l}$, while the anthocyanin content of the product at $8^{\circ} \mathrm{C} \pm$ $2^{\circ} \mathrm{C}$ was 1.45 times higher than the sample stored at $28^{\circ} \mathrm{C} \pm 2^{\circ} \mathrm{C}$. By the eighth week, at $28^{\circ} \mathrm{C} \pm 2^{\circ} \mathrm{C}$, this content decreased significantly to $5.62 \mathrm{mg} / \mathrm{l}$ whereas, at $8^{\circ} \mathrm{C} \pm 2^{\circ} \mathrm{C}$, the anthocyanin content of the product remained higher (2.72-fold higher). This decrease could be explained by the strong impact of the storage environment 


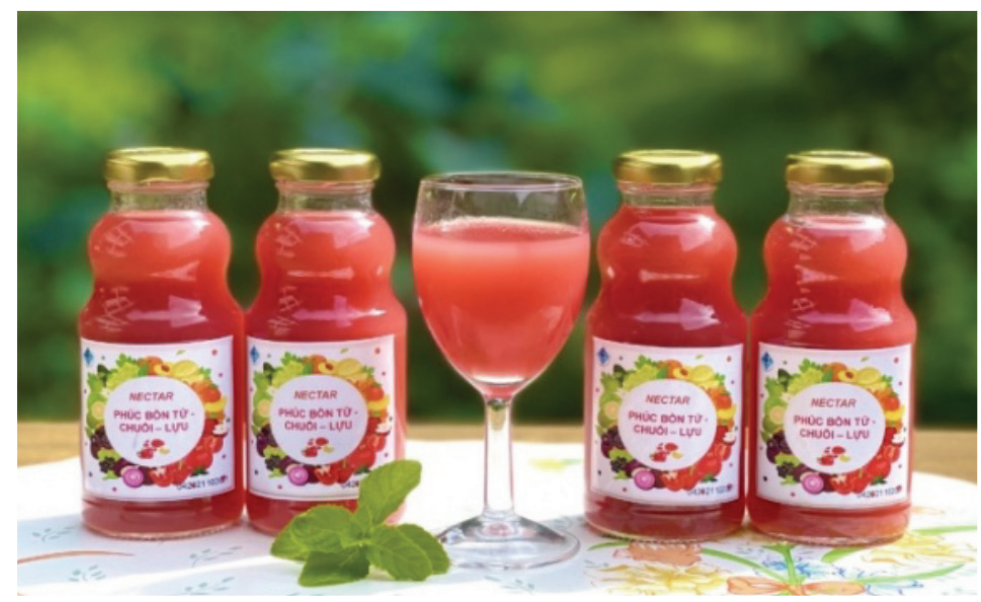

Figure 3: Raspberry-pomegranate-banana nectar product ( 7 minutes pasteurized at $85^{\circ} \mathrm{C}$ and 8 -week storage at $8^{\circ} \mathrm{C} \pm 2{ }^{\circ} \mathrm{C}$ ).

temperature leading to a significant change in anthocyanin content in the product. This result was similar to that reported by Kopjar et al. [34], where the loss of anthocyanin content in the strawberry jam when it was stored at $4^{\circ} \mathrm{C}$ was higher than in those stored at room temperature. Bakker et al. [35] found that strawberry puree and juice lost almost $50 \%$ anthocyanin content after 3 weeks of storage at $20^{\circ} \mathrm{C}$, while there was little or no change in content in the sample that was kept at low temperature $\left(-20^{\circ} \mathrm{C}\right)$ after 8 weeks.

The anthocyanin content of the product was strongly degraded at $28^{\circ} \mathrm{C} \pm 2{ }^{\circ} \mathrm{C}$ after 8 weeks of storage, causing the nectar to lose its red color, and at the same time, the signs of oxidation began to appear, causing the product to turn brown, while in cool conditions $\left(8^{\circ} \mathrm{C} \pm 2^{\circ} \mathrm{C}\right)$ the nectar retained its bright red color after 8 weeks of investigation (Fig. 3). In addition, anthocyanin content is also sensitive to $\mathrm{pH}$ because nectar products have a low $\mathrm{pH}$ of 3.8 \pm 0.2 , so to avoid darkening a moderate temperature should be chosen for pasteurization and storage [36,37]. Factors affecting the stability of anthocyanin content can be actively controlled such as direct light shining on and storing products at low temperature to limit the reactions that decompose color pigments [22]. As shown in Table 3, the half-lives of anthocyanin in the combined nectar at $8^{\circ} \mathrm{C} \pm 2{ }^{\circ} \mathrm{C}$ and $28^{\circ} \mathrm{C} \pm 2{ }^{\circ} \mathrm{C}$ were 11.76 and 4.5 weeks, respectively. At low temperatures, mixed nectar anthocyanins are $\sim 3$ times less susceptible to degradation than they are at a higher temperature. It could be concluded that the stability of anthocyanin in the mixed nectar was high at low temperatures. After 8 weeks, the sensory characteristics of these products remained (data were not shown).

\section{CONCLUSION}

The kinetics of anthocyanin degradation during heat processing as well as storage at different temperatures followed a first-order kinetic model, so anthocyanin changes could be fully predicted. From the results obtained, it is recommended that the product be added to $100 \mathrm{ppm}$ ascorbic acid combined with $100 \mathrm{ppm}$ citric acid, heated at $85^{\circ} \mathrm{C}$ for 7 minutes, and stored at $8^{\circ} \mathrm{C} \pm 2^{\circ} \mathrm{C}$ to ensure the maintenance of product quality and sensory value. By using the acquired models, the producer or consumer could assess the quality of the product during processing and storage, and they are applied to predict the quality change of the product in industrial production.

\section{AUTHOR CONTRIBUTIONS}

All authors made substantial contributions to conception and design, acquisition of data, or analysis and interpretation of data; took part in drafting the article or revising it critically for important intellectual content; agreed to submit to the current journal; gave final approval of the version to be published; and agree to be accountable for all aspects of the work. All the authors are eligible to be an author as per the international committee of medical journal editors (ICMJE) requirements/guidelines.

\section{FUNDING}

There is no funding to report.

\section{CONFLICTS OF INTEREST}

The authors report no financial or any other conflicts of interest in this work.

\section{ETHICAL APPROVALS}

This study does not involve experiments on animals or human subjects.

\section{PUBLISHER'S NOTE}

This journal remains neutral with regard to jurisdictional claims in published institutional affiliation.

\section{REFERENCES}

1. Stewart D, McDougall GJ, Sungurtas J, VerrallS, Graham J, Martinussen, I. Metabolomic approach to identifying bioactive compounds in berries: advances toward fruit nutritional enhancement. Mol Nutr Food Res 2017;51(6):645-51; http://doi.org/10.1002/ mnfr.200700056

2. Suh JH, Romain C, González-Barrio R, Cristol JP, Teissèdre PL, Crozier A, et al. Raspberry juice consumption, oxidative stress and reduction of atherosclerosis risk factors in hypercholesterolemic golden Syrian hamsters. Food Funct 2011;2(7):400-5; http://doi org/10.1039/c1 fo10047e

3. Aviram M, Dornfeld L, Rosenblat M, Volkova N, Kaplan M, Coleman $\mathrm{R}$, et al. Pomegranate juice consumption reduces oxidative stress, atherogenic modifications to LDL, and platelet aggregation: studies in 

ascorbic acid and citric acid 2022;10(01):189-195

humans and in atherosclerotic apolipoprotein E-deficient mice. Am J Clin Nutr 2000;71(5):1062-76; http://doi.org/10.1093/ajcn/71.5.1062

4. Zarfeshany A, Asgary S, Javanmard SH. Potent health effects of pomegranate. Adv Biomed Res 2014;3:100; http://doi. org/10.4103/2277-9175.129371

5. Maskan M. Microwave/air and microwave finish drying of banana original. J Food Eng 2000;44:71-8; http://doi.org/10.1016/S02608774(99)00167-3

6. Tapre AR, Jain RK. Study of inhibition of browning of clarified banana juice. Asian J Dairy Food Res 2016;35(2):155-9; http://doi. org/10.18805/ajdfr.v35i2.10723

7. Matsuura FCAU, Folegatti MIDS, Cardoso RL, Ferreira DC. Sensory acceptance of mixed nectar of papaya, passion fruit and acerola. Sci Agric 2004;61:604-8; http://doi.org/10.1590/S010390162004000600007

8. Landbo AK, Meyer AS. Effects of different enzymatic maceration treatments on enhancement of anthocyanin and other phenolics in black currant juice. Innovative Food Sci Emerg Technol 2004;5(4):503-13; http://doi.org/10.1016/j.ifset.2004.08.003

9. AtalaE,Vásquez L, Speisky H, Lissi E, López-Alarcón C. Ascorbic acid contribution to ORAC values in berry extracts: an evaluation by the ORAC-pyrogallol red methodology. Food Chem 2009;113:331-5; http://doi.org/10.1016/j.foodchem.2008.07.063

10. Giusti MM, Wrolstad RE. Acylated anthocyanins from edible sources and their applications in food systems. Biochem Eng J 2003;14(3):21725; http://doi.org/10.1016/S1369-703X(02)00221-8

11. Hellstrom J, Mattila P, Karjalainen R. Stability of anthocyanins in berry juices stored at different temperatures. J Food Compos Anal 2013;31(1):12-9; http://doi.org/10.1016/j.jfca.2013.02.010

12. Kopjar M, Jakšić K, Piližota V. Influence of sugars and chlorogenic acid addition on anthocyanin content, antioxidant activity and color of blackberry juice during storage. J Food Process Preserv 2012;36(6):545-52; http://doi.org/10.1111/j.1745-4549.2011.00631.x

13. Del Pozo-Insfran D, Del Follo-Martinez A, Talcott ST, BrenesCH. Stability of copigmented anthocyanins and ascorbic acid in muscadine grape juice processed by high hydrostatic pressure. J Food Sci 2007;72(4):S247-53; http://doi.org/10.1111/j.17503841.2007.00316.x

14. Tadakittisarn S, Haruthaithanasan V, Chompreeda P, Suwonsichon T. Optimization of pectinase enzyme liquefaction of banana GrosMiche' for banana syrup production. Agric Nat Resour 2007;41(4):740-50.

15. Tezcan F, Gültekin-Özgüven M, Diken T, Özçelik B, Erim FB. Antioxidant activity and total phenolic, organic acid and sugar content in commercial pomegranate juices. Food Chem 2009;115(3):873-7; http://doi.org/10.1016/j.foodchem.2008.12.103

16. Charurungsipong $\mathrm{P}$, Tangduangdee $\mathrm{C}$, Amornraksa S, Asavasanti S, Lin J. Improvement of anthocyanin stability in butterfly pea flower extract by co-pigmentation with catechin. E3S Web Conf 2020;141:03008; http://doi.org/10.1051/e3sconf/202014103008

17. Harbourne N, Jacquier JC, Morgan DJ, Lyng JG. Determination of the degradation kinetics of anthocyanins in a model juice system using isothermal and non-isothermal methods. Food Chem 2008;111(1):2048; http://doi.org/10.1016/j.foodchem.2008.03.023

18. Wang WD, Xu SY. Degradation kinetics of anthocyanins in blackberry juice and concentrate. J Food Eng 2007;82(3):271-5; http://doi. org/10.1016/j.jfoodeng.2007.01.018

19. Garzon GA, Wrolstad RE. Comparison of the stability of pelargonidinbased anthocyanins in strawberry juice and concentrate. J Food Sci 2002;67(4):1288-99; http://doi.org/10.1111/j.1365-2621.2002. tb10277.x

20. Kirca A, Ozkan M, Cemeroglu B. Effects of temperature, solid content and $\mathrm{pH}$ on the stability of black carrot anthocyanins. Food Chem 2007;101(1):212-8; http://doi.org/10.1016/j.foodchem.2006.01.019

21. Turturică M, Stănciuc N, Bahrim G, Râpeanu G. Effect of thermal treatment on phenolic compounds from plum (Prunusdomestica) extracts-a kinetic study. J Food Eng 2016;171:200-7; http://doi. org/10.1016/j.jfoodeng.2015.10.024
22. Martinez MV, Whitaker JR. The biochemistry and control of enzymatic browning. Trends Food Sci Technol 1995;6(6):195-200; http://doi org/10.1016/S0924-2244(00)89054-8

23. Abd-Elhady M. Effect of citric acid, calcium lactate and low temperature prefreezing treatment on the quality of frozen strawberry. Ann Agric Sci 2014;59(1):69-75; http://doi.org/10.1016/j.aoas.2014.06.010

24. Shaheer CA, HafeedaP, Kumar R, Kathiravan T, Kumar D, Nadanasabapathi S. Effect of thermal and thermosonication on anthocyanin stability in jamun (Eugenia jambolana) fruit juice. Int Food Res J 2014;21(6):2189.

25. Rubinskiene M, Viskelis P, JasutieneI, Viskeliene R, Bobinas C. Impact of various factors on the composition and stability of black currant anthocyanins. Food Res Int 2005;38(8-9):867-71; http://doi. org/10.1016/j.foodres.2005.02.027

26. Nielsen SS, Marcy JE, Sadler GD. Chemistry of aseptically processed foods. In: Chambers JV, Nelson PE (eds.). Principles of aseptic processing and packaging, Food Processors Institute, Washington, DC, p 87e114, 1993.

27. Martynenko A, Chen Y. Degradation kinetics of total anthocyanins and formation of polymeric color in blueberry hydrothermodynamic (HTD) processing. J Food Eng 2016;171:44-51; http://doi. org/10.1016/j.jfoodeng.2015.10.008

28. Sui X, Dong X, Zhou W. Combined effect of $\mathrm{pH}$ and high temperature on the stability and antioxidant capacity of two anthocyanins in aqueous solution. Food Chem 2014;163:163-70; http://doi.org/10.1016/j. foodchem.2014.04.075

29. Kırca A, Cemeroğlu B. Degradation kinetics of anthocyanins in blood orange juice and concentrate. Food Chem 2003;81(4):583-7; http:// doi.org/10.1016/S0308-8146(02)00500-9

30. Danışman G, Arslan E, Toklucu AK. Kinetic analysis of anthocyanin degradation and polymeric colour formation in grape juice during heating. Czech J Food Sci 2015;33(2):103-8; http://doi. org/10.17221/446/2014-CJFS

31. Hillmann MC, Burin VM, Bordignon-Luiz MT. Thermal degradation kinetics of anthocyanins in grape juice and concentrate. Int J Food Sci Technol 2011;46(9):1997-2000; http://doi.org/10.1111/j.13652621.2011.02694.x

32. Thuy NM, Banyavongsa A, Tai NV. The effect of homogenization and sterilization on the stability and nutritional evaluation of Vietnamese purple rice milk supplemented with sesame, soybean and water caltrop. Food Res 2020;4(6):2289-95; http://doi.org/10.26656/ fr.2017.4(6).379

33. Francis FJ, Markakis PC. Food colorants: anthocyanins. Crit Rev Food Sci Nutr 1989;28(4):273e314; http://doi. org/10.1080/10408398909527503

34. Kopjar M, Piližota V, Tiban NN, ŠubarićD, Babić J, Ačkar Đ, et al. Strawberry jams: influence of different pectins on colour and textural properties. Czech J Food Sci 2009;27(1):20-8; http://doi. org $/ 10.17221 / 95 / 2008-C J F S$

35. Bakker J, Bridle P, Koopman A. Strawberry juice colour. The effect of some processing variables on the stability of anthocyanins. J Sci Food Agric 1992;I:471; http://doi.org/10.1002/jsfa.2740600411

36. Chen CR, RamaswamyHS. A neuro-computing approach for modeling of residence time distribution (RTD) of carrot cubes in a vertical scraped surface heat exchanger (SSHE). Food Res Int 2000;33(7):549 56; http://doi.org/10.1016/S0963-9969(00)00090-9

37. Fellows PJ. Food processing technology: principles and practice. Elsevier, 2009; http://doi.org/10.1533/9781845696344

\section{How to cite this article:}

Thuy NM, Han LN, Tai NV. Thermal stability of anthocyanin in mixed raspberry-pomegranate-banana nectar in the presence of ascorbic acid and citric acid. J Appl Biol Biotech 2022; 10(01):189-195. 